\title{
GRAĐEVNI OTPAD KAO VAŽAN ELEMENT DRUŠTVENO ODGOVORNOG POSLOVANJA MANJIH GRAĐEVINSKIH PODUZEĆA
}

\author{
Lana Lovrenčić Butković, Anđela Radić Stanišić i Mislav Ante Omazić \\ Građevinski fakultet Sveučilišta u Zagrebu \\ Kačićeva ulica 26, 10000 Zagreb \\ e-mail: llovrencic@grad.hr
}

\begin{abstract}
Sažetak
Društveno odgovorno poslovanje poduzeća nije reaktivan koncept koji se dogada isključivo uslijed pritiska dionika, već nalaže konkretne aktivnosti koje uključuju odgovornost menadžera da donose odluke koje će biti uravnoteže između interesa raznih dionika, zaštite okoliša na koje poduzeće ima (in)direktni utjecaj te njegovih ekonomskih ciljeva. Danas se od poslovnih organizacija očekuje poslovanje u skladu s dugoročnim razvojnim strategijama koje impliciraju sustavan pristup održivom razvoju svih elemenata društva na koje poduzeće ima utjecaj. Cilj je ovoga rada ukazati na važnost gospodarenja otpadom, prije svega gradevnim, kao dijela koncepta druśtveno odgovornog poslovanja gradevinskih poduzeća, jer poduzeća u njemu sve više prepoznaju temelj svoje održivosti $i$ konkurentnosti. U tom smislu se društveno odgovorno poslovanje sve snažnije integrira u strategije, ali i operativne poslove jer se samo ovakvim pristupom ostvaruju bolji poslovni rezultati i stječe održiva konkurentna prednost. Kada se mjeri društveno odgovorno poslovanje poslovnih entiteta, iako se gledaju tri ključna aspekta izvedbe (društveni, ekonomski i okolišni), važna je i njihova medusobna interakcija te ravnoteža. S obzirom na to da djelatnost gradevinarstva ima značajan utjecaj na okoliš, ovaj članak razmatra i analizira može li se uspješno upravljanje gradevnim otpadom optimizirati, prvenstveno iz okolišne perspektive, ali i iz ekonomske te društvene. U članku je prikazana i podjela gradevnog otpada te gospodarenje njime. Kako bi se ostvario cilj rada, provedeno je istraživanje putem intervjua u četiri poduzeća koja se bave sakupljanjem i reciklažom gradevnog otpada. Dobiveni rezultati pokazali su da su ispitana poduzeća najviše otpada prikupili od srednjih i velikih gradevinskih poduzeća, a u 2018. izvezli su ukupno 53\% sakupljenog otpada.
\end{abstract}

Ključne riječi: društveno odgovorno poslovanje, gradevinska industrija, upravljanje otpadom, zaštita okoliša, zbrinjavanje gradevnog otpada

\section{UVOD}

Živimo u dobu u kojem čovjek svojim djelovanjem nepovratno uništava dostupne mu resurse (DeAngelis, 2018). Nobelovci Crutzen i Stoermer su 2000. anticipirali doba nove geološke epohe Antropocena koje ističe kako je čovjekov negativan utjecaj na Planet dosegao neslućene razmjere i rezultira gubitkom mnogih ekosustava (De Angelis, 2018). Čak i najnapredniji sustavi gospodarenja otpadom koji su u funkciji imaju svoja ograničenja i niti jedan ne obuhvaća cijeli ciklus gospodarenja otpadom od njegove 
prevencije do finalnog zbrinjavanja iako svi tome streme (Morrissey i Browne, 2004). Procjenjuje se kako je između 1900. i 2000. globalni BDP narastao preko 20 puta (Tonelli i Cristoni, 2019), što je za rezultat imalo i ogromnu devastaciju okoliša. Nakon industrijske revolucije 1880-tih, a posebno nakon II. svjetskog rata, čovječanstvo proživljava, do tada nikad viđeni, stalan rast koji je postepeno počeo ugrožavati naš postojanje na Planetu. Tijekom 20. stoljeća globalna se ekonomija nije inkrementalno, već radikalno mijenjala kroz ubrzanu industrijalizaciju mnogih geografskih regija. Ta je industrijalizacija stalno poticana novim i učinkovitijim proizvodnim tehnologijama, sve nižom relativnom cijenom radne snage, kreiranjem ekonomije obujma i progresivnom globalizacijom tržišta koja je rezultat niskih transportnih troškova te sve dostupnijom informacijsko-komunikacijskom tehnologijom koja je generator eksponencijalnog stvaranja novih informacija i znanja. Sve to je utjecalo i na građevinsku industriju u kojoj se mogu primijetiti trendovi poput sve snažnije digitalizacije ključnih procesa, korištenja umjetne inteligencije i robota u svim fazama razvoja projekta, umrežavanja inteligentnih sustava gradnje, printa 3-D konstruktivnih elemenata te sve snažnijim impulsima za zelenom gradnjom (Building Radar, 2020; Deloitte, 2020).

Uloga se poduzeća u suvremenom društvu bitno izmijenila u proteklih 50 godina. Suvremeno društvo pred menadžment poslovnih organizacija stavlja brojne izazove kao što je ostvarivanje poslovnih rezultata, ali vodeći brigu o zajednici unutar koje djeluju. $\mathrm{Na}$ samom početku važno je istaknuti kako je društvena odgovornost poduzeća koncept koji je veoma teško precizno definirati i izmjeriti. Prije svega ono se odnosi na promijenjenu ulogu poduzeća u suvremenom društvu. Ta se uloga razlikuje od društva do društva, jer različiti dionici u različitim društvima imaju različitu moć i nisu spremni djelovati na isti način. Definicija društvene odgovornosti poduzeća (dalje u radu DOP-a) multidimenzionalni je konstrukt koji obuhvaća razne čimbenike i elemente (Rasche i sur., 2017). Europska komisija određuje društvenu odgovornost poduzeća kao strateški koncept unutar kojeg poduzeća na dobrovoljnoj bazi integriraju društvene i okolišne dimenzije u svoje poslovne operacije kao i svoje odnose s dionicima; s ciljem maksimalne kreacije zajedničke vrijednosti za dionike i društvo te identificiranja, sprečavanja i mitigacije mogućih negativnih utjecaja (Europska komisija, 2019d).

U gotovo svim definicijama ističe se konstruktivna uloga poduzeća u društvu, jer poduzeće teško može opstati unutar negativnog konteksta koji ga oblikuje. Tako se društveno odgovorno poslovanje može odrediti kao društvena aktualnost koja neprestano mijenja svoju pojavnost ovisno o čimbenicima koji na nju utječu, jer se strategije stalno prilagođavaju stvarnosti mijenjajući pri tome i granice odgovornosti poduzeća te silnice njegova utjecaja (Bačun i sur., 2012). Najšira definicija obuhvaća integraciju društvenog, okolišnog, upravljačkog, filantropskog i ekonomskog djelovanja poduzeća prema društvu u vlastite operacije, procese te sržnu poslovnu strategiju, temeljem interesa i utjecaja ključnih dionika. Važno je istaknuti kako se bitno ne mijenja jedinstvena i osnovna uloga poduzeća, a to je stvaranje ekonomske vrijednosti, no činjenica je da su poduzeća najmoćniji i najučinkovitiji entiteti društva te se u tom smislu od njih očekuje da redistribuiraju dio stvorene novostvorene vrijednosti. Dakle i dalje poduzeća ima- 
ju za svoj primarni cilj stvarati profit, samo što taj cilj nije maksimizacija profita, već njegova optimizacija kroz konstruktivno djelovanje prema društvu i okolišu. Danas se uspješnost poduzeća u velikom broju slučajeva ne mjeri samo ostvarenim profitom, već količinom pozitivnog utjecaja prema svim dionicima u društvu, kao i društvu općenito. U posljednjih se 20 -ak godina u znanstvenoj literaturi sve veća pažnja posvećuje malim i srednjim poduzećima (Jenkins, 2004; Jenkins, 2006; Perrini, 2006; Murillo i Lozano, 2006; Ciliberti i sur., 2008; Russo i Tencati, 2009; Jamali i sur., 2009; Del Baldo, 2018, Awan i sur., 2019). Ovo je područje znanstveno interesantno iz nekoliko perspektiva, posebno u europskom kontekstu, jer upravo u Europi primjetan je snažan porast interesa za ovo područje (Matten i Moon, 2008). Mala i srednja poduzeća zapošljavala su tijekom 2017. više od 94 milijuna ljudi ili 66\% ukupnog broja radne snage (Clark, 2019). U 2018. 56\% novostvorene vrijednosti u Europskoj uniji proizašlo je od 25,1 milijun malih i srednjih poduzeća i to (Clark, 2019):

- 23,4 milijuna (ili 93,5\%) mikro poduzeća s 1 do 9 zaposlenika;

- $\quad 1,47$ milijuna (ili 5,6\%) malih s 10 do 49 zaposlenika te

- $\quad 236.000$ (ili 0,9\%) srednjih s 50 do 249 zaposlenika.

Djelomično je tome razlog i specifična priroda malih i srednjih poduzeća kao i njezinih karakteristika poput veličine, djelatnosti i vlasničke / menadžerske orijentacije prema profitu (Braun, 2010). Pored ovih specifičnosti, Ciliberti i suradnici (2008) navode i povezanost poslovnog modela s lokalnom zajednicom, načina na koji poduzeća stvaraju vrijednost, dostupnost resursa te ravnoteže kratkoročnih i dugoročnih ciljeva. Murillo i Lozano (2006) navode kao ključne izazove kompatibilnosti sustava vrednota menadžera (osnivača / vlasnika) i društveno odgovornih programa te informiranje ključnih unutrašnjih i vanjskih dionika o najboljim praksama koji nisu jasno informirani na koji način društveno odgovorna praksa utječe na konkurentnost i ekonomsku izvedbu malih i srednjih poduzeća. Perrini (2006) na kraju tvrdi kako bi se velika poduzeća trebala promatrati iz perspektive dioničke teorije, a mala i srednja poduzeća iz perspektive stvaranja društvenog kapitala. Russo i Tencati (2009) razlikuju formalnu i neformalnu društveno odgovornu praksu malih i srednjih poduzeća te često ističu kako ona imaju sjajne primjere koji često ostaju skriveni, jer su nejasno artikulirani te su nepoznati široj javnosti. Kako bi čim jasnije, učinkovitije i transparentnije komunicirala svoju ulogu u društvu, poduzeća su u proteklih 20 -ak godina pored financijskih počela izdavati i nefinancijska izvješća, i to sve češće u formi integriranih izvještaja koji daju jasniju sliku o njihovoj prošlosti, sadašnjosti i budućnosti. Osnovna je funkcija tih izvješća informiranje. Dakle, menadžment poduzeća kroz nefinancijske izvještaje informira zainteresiranu javnost o odgovornosti, obvezama te utjecaju na svoje (in)direktno okruženje. Glavni motiv menadžmentu za izdavanje ove vrste izvješća, ali i informacija, upravljanje je reputacijom kao i jasno pozicioniranje poduzeća iz perspektive načina i oblika stvaranja vrijednosti za društvo. Iako je projekcija budućnosti ovakve vrste izvještaja prije 15-ak godina bila relativno pesimistična, današnja slika bitno je drugačija (Owen i O’Dwyer, 2008). U članku će se analizirati utjecaj DOP-a građevinske djelatnosti na temelju analize gospodarenja građevnim otpadom. U građevinskoj je djelatnosti jedan od najvažnijih ele- 
menata okolišnog segmenta otpad i gospodarenje otpadom. Neki od razloga važnosti gospodarenja (građevnim) otpadom su: divlja odlagališta, neadekvatno zbrinjavanje opasnog i neopasnog građevnog otpada, nedostatak reciklažnih dvorišta, neosviještenost kompanija za brigu o okolišu i dr. Cilj je ovoga rada ukazati na važnost gospodarenja građevnog otpadom, kao dijela koncepta društveno odgovornog poslovanja.

\section{POJAM I ZNAČENJE TE DEFINIRANJE DOP-A - VELIČINA PODUZEĆA JE VAŽNA}

Društvena odgovornost poduzeća, nije više toliko nov pojam u poslovanju jer se započeo oblikovati 50 -ih godina 20. stoljeća. Općenito početkom ili točkom preokreta smatra se 1953. i izdavanje knjige Social Responsibilities of the Businessman američkog autora Howarda R. Bowena. Do 50-ih prevladavalo je filantropsko doba jer su poslovne organizacije i ljudi uglavnom donirali potrebite bilo da se radi o pojedincima ili društvu korisnim organizacijama i inicijativama. Period od 1953. do 1967. klasificira se kao faza buđenja svijesti u kojem menadžment poslovnih organizacija prepoznaje važnost svoje uloge u društvu, kao i odgovornost naspram te uloge. Period od 1968. do 1973. naziva se fazom konkretizacije u kojem se menadžment poduzeća fokusirao na konkretne probleme koji su tištali društvo poput propadanja urbanih središta, rasne diskriminacije i zagađenja okoliša. Konačno nakon 1974. poslovne organizacije prepoznale su kako one moraju voditi primjerom i identificirati se $s$ ključnim problemima u društvu i imati sustavan pristup rješavanju problema te se fokusirati na uzroke, a ne posljedice. Jasno je kako je put koji je DOP prošao od nerealne vizije do konsolidirane komercijalne stvarnosti ovisio o povezivanju ključnih poslovnih segmenata u kojima se na poduzeće gleda kao na rješenje, a ne uzrok društvenih problema (Midttun, 2013). Premda korijeni društveno odgovornog poslovanja sežu u davne 50-te, Carroll (2015) povezuje nagli razvoj područja s globalizacijskim procesima koji se intenziviraju 90-ih.

Kao što je već ranije napisano, ne postoji jedna univerzalna definicija DOP-a. Štoviše, često se u praksi umjesto DOP-a koriste termini poput korporativnog građanstva, konstruktivne uloge poduzeća u društvu, održivosti ili poslovne etike, koji nisu i ne mogu biti istoznačnice. To je pogrešno, jer ako govorimo o etici ili specifičnije poslovnoj etici, onda je jasno kako se ovdje u fokus stavlja pojedinac te način na koji donosi odluke i djeluje u poslovnom okruženju te kako je to djelovanje povezano sa sustavom vrednota. Poslovnu etiku možemo definirati kao sustav poslovnih pravila koji upravlja sustavom vrednota u poslovnoj interakciji između pojedinaca (Bačun i sur., 2012). Poslovna etika povezana je $s$ DOP-om, jer se stručnost i profesionalizam ističu kao temelj svakog posla, a etički kodeks kao podlogu tih svojstava (Khanka, 2014). Isključivo menadžment u kojem su svi ili velika većina pojedinaca etični, može biti i društveno odgovoran. Ako pišemo o održivosti i modelima povezanim $s$ tim konceptom, onda problemu prilazimo iz kibernetske perspektive i u fokus stavljamo odnos elemenata u sustavu i promišljanju načina na koji se sustavno problemi mogu riješiti. Kako koncept održivog razvoja sugerira, današnje bi generacije trebale ispuniti svoje potrebe, a da se pri tome ne unište 
mogućnosti budućih generacija da ostvare svoje.

Upravo polazeći od te perspektive a kao što je i ranije istaknuto, Europska unija ističe DOP kao temelj vlastite konkurentnosti te njegovu važnost iz tri perspektive (Europska komisija, 2019c):

1. DOP je važan za poduzeća jer osigurava koristi iz perspektive upravljanja rizicima, troškovne učinkovitosti, dostupnosti jeftinijih izvora financiranja, snažnijih odnosa s kupcima, boljih odnosa sa zaposlenicima, inovacija i ultimativno profita.

2. DOP je važan za tržište jer potiče održivost poslovnih modela i inovacije što doprinosi održivoj ekonomiji.

3. DOP je važan za društvo jer potiče određeni sustav vrednota koje su komplementarne kohezivnom društvu i koje mogu postati osnova za tranziciju na održive ekonomske sustave.

Društvena odgovornost poduzeća predstavlja dugoročni proces civiliziranja kapitalizma ili poticanja odgovornosti koju poduzeća imaju naspram svog utjecaja na društvo i okoliš na globalnom ekonomskom tržištu (Midttun, 2013). Svjesnost o potrebi redefiniranja uloge menadžmenta i poslovnih organizacija u suvremenom svijetu nije nešto novo, međutim ono što je relativno novo jest da su silnice utjecaja postale toliko snažne da ih je gotovo nemoguće ignorirati te je evidentno kako se uloga poduzeća u suvremenom društvu iz temelja mijenja.

Europska komisija društveno odgovorno poslovanje određuje kao koncept unutar kojeg poduzeća na dobrovoljnoj bazi integriraju društvene i okolišne dimenzije u svoje poslovne operacije te svoje odnose s dionicima (Europska komisija, 2019c). DOP je složen jer predstavlja koncept koji nastoji uravnotežiti nekoliko različitih i naoko suprotstavljenih dimenzija poslovanja:

- dugoročne i kratkoročne ciljeve;

- upravljačku, ekonomsku, okolišnu i društvenu sferu utjecaja;

- interese i utjecaj različitih dionika;

- različite funkcije menadžmenta i to planiranje, organiziranje, vođenje, ljudske potencijale i kontroliranje (kao i njegove meta-funkcije poput motiviranja zaposlenika, donošenja odluka ili menadžmenta promjena).

Zbog toga društvena odgovornost poduzeća predstavlja aktualnost i konstantno mijenja svoju pojavnost mijenjajući pri tome i granice menadžerske odgovornosti (Omazić, 2008). Ona je situacijski fenomen koji se razvija putem pregovaračkog procesa svih dionika o ulozi poduzeća u konkretnom društvu i odgovornosti naspram te uloge. DOP implicitno i eksplicitno pomaže u izgradnji povjerenja, a ono je od izuzetne važnosti za sva poduzeća kojima je interakcija s raznim dionicima jedan od ključnih čimbenika poslovanja. Naime, većina će dionika od samog početka lakše poslovati s poduzećima koja primjenjuju ovaj koncept i koja se odnose odgovorno prema zajednici u kojoj posluju jer postoje preduvjeti za uspostavljanje povjerenja. DOP je koncept u okviru kojeg društva dugoročno i kratkoročno integriraju u svoje poslovanje interakciju sa svim akterima društva i izazove vezane za prirodnu okolinu, na dobrovoljnoj osnovi, ali 
iznad onoga što je zakonom propisano. Subjekti koji ga usvajaju svjesno i dobrovoljno, nadilaze svoju primarnu funkciju stjecanja i raspodjele ekonomskih renti i ostvaruju pozitivan utjecaj na svoje radno, društveno i prirodno okruženje. DOP predstavlja svijest o novom položaju i značaju koja poduzeća imaju u suvremenom, globalno umreženom društvu. Ta odgovornost proizlazi iz privilegirane pozicije koju menadžment poduzeća ima u današnjem društvu. To je zapravo proces u kojem poslovne organizacije usklađuju svoje odnose primarno s ključnim dionicima, a potom i s najraznovrsnijim društvenim akterima koji mogu (mada i ne moraju) imati utjecaj na njihovo poslovanje. Praksa DOP-a odnosi se na cjelokupnu sferu utjecaja i raspon djelovanja jednog poduzeća, kao i na odnose koje ono pri tome uspostavlja: koje usluge ili proizvode nudi; kako nabavlja sve oblike resursa; pridržava li se zakona; poštuje li ljudska, dječja te radna prava; na koji način zapošljava, osposobljava i utječe na razvoj ljudskih potencijala; koliko ulaže u lokalnu zajednicu; na koji način doprinosi očuvanju životne sredine i okoliša; inovira li i na koji način zadovoljava potrebe kupaca ili klijenata. Iako raste broj poduzeća koji prepoznaju potrebu za primjenu DOP-a, pri integraciji te ideje u svakodnevno upravljanje, uključujući cijeli dobavljački lanac, zaposlenike i menadžere, potrebno je usvajanje dodatnih kompetencija kao i sustav stalnog unapređenja postojećih procesa i projekata. Iako kada se piše o DOP-u najčešće se koncept determinira kroz prizmu velikih poslovnih organizacija, no to nikako ne znači kako DOP nije primjenjiv u manjim poduzećima. Aktivnosti DOP-a u manjim poduzećima razlikuju se od istih u velikim poduzećima (Baumann-Pauly i sur., 2013). Kod njih je često želja za implementacijom koncepta DOP-a u poslovanje temeljena na osobnoj motivaciji, sustavu vrednota i inspiraciji osnivača (koji je u velikom broju slučajeva ujedno i vlasnik te menadžer). Kod velikih je poduzeća osnovni motiv za DOP osnaživanje odnosa s dionicima te reputacijom koja će rezultirati pozitivnim novčanim tijekom (Rasche i sur., 2017). Ovdje je uloga manjih poduzeća specifična jer ona često nemaju resurse za sustavnu implementaciju praksi DOP-a, ali ih provode neformalno, spontano i intuitivno kroz povećanu brigu za zaposlenike, lokalnu zajednicu i snažnije odnose s partnerima. Premda se DOP možda drugačije operacionalizira i razumijeva u manjim poduzećima od velikih, postoji niz zajedničkih poveznica. Prije svega razlozi koji leže u konkurentnosti jednaki su pa je i argumentacija slična, jer su neki principi poput pravednosti i povjerenja univerzalni bez obzira na veličinu poduzeća. Na kraju, iako DOP možda ima namjeru biti svemoguć, on nikako nije univerzalni lijek za sve društvene probleme te bi poduzeća (posebno ona mala) trebala jasno determinirati društvene i okolišne probleme u rješavanju kojih žele pomoći te bi o tome trebala jasno komunicirati prema svojim dionicima. Ponekad je zadovoljavanje zakonskog minimuma izazov, posebno u tranzicijskim ekonomijama u kojima je regulatorni okvir u stanju stalnog fluksa (Rasche i sur., 2017).

U strukturi građevinskih poduzeća u Hrvatskoj, mala poduzeća čine udio od oko 98\% u ukupnom broju građevinskih poduzeća. Točnije, od ukupno 15.245 registriranih poduzeća u području F Građevinarstvu u 2019., mikro i malih poduzeća bilo je 14.993 (98,34\%) (DZS, 2020). Unatoč velikom broju mikro i malih građevinskih poduzeća, jedna od specifičnosti građevinske industrije je ta što srednja i velika građevinska po- 
duzeća ostvaruju oko 90\% ukupnog prihoda industrije. A ako se uzme u obzir i velika masa korištenih materijala u procesu građenja i njihovim utjecajem na okoliš, upravo upravljanje otpadom korištenog materijala može predstavljati značajnu komponentu u implementaciji DOP-a u velikim, ali i malim građevinskim poduzećima.

\section{GRAĐEVNI OTPAD - PRILIKA ILI PRIJETNJA}

Građevni otpad nastaje u svim fazama izvedbe građevinskih projekata, kao i tijekom cijelog životnog vijeka građevina, uključujući gradnju, upotrebu / održavanje i rušenje te ponovnu izgradnju (Štirmer i sur., 2017). Prema Zakonu o održivom gospodarenju otpadom (NN 94/13) građevni je otpad onaj nastao prilikom gradnje građevina, rekonstrukcije, uklanjanja i održavanja postojećih građevina te otpad nastao od iskopanog materijala, koji se ne može bez prethodne oporabe koristiti za građenje građevine zbog kojeg je građenja nastao. Upravo iz navedenih razloga, građevni otpad predstavlja važan segment u definiranju i korištenju okolišnog aspekta društveno odgovornog poslovanja.

\subsection{Vrste gradevnog otpada}

Građevni otpad sastoji se od različitih vrsta materijala ovisno o vrsti građevinskog objekta, izvedenim radovima, te gradi li se, ruši ili rekonstruira objekt. Općenito, vrste materijala koje se mogu javiti u građevinskom otpadu ovise o vrsti radova u građevinarstvu što je definirano u Planu gospodarenja otpadom u RH za razdoblje 2007.-2015. (NN 85/07). Tako je npr. tijekom zemljanih radova građevni otpad zemlja, pijesak, šljunak, glina, ilovača, kamen. U poslovima u sektoru niskogradnje izdvaja se bitumen (asfalt) ili cementom vezani materijal, pijesak, šljunak, drobljeni kamen, dok u sektoru visokogradnje otpad je beton, opeka, mort, gips, plinobeton, prirodni kamen. Miješanim građevinskim otpadom smatra se drvo, plastika, papir, karton, metal, kablovi, boja, lak, šuta.

Vrste građevinskog otpada također se razlikuju ovisno o tome ruši li se postojeća ili se gradi nova građevina. Uzevši u obzir geografske specifičnosti RH, u Dalmaciji i Primorju kao građevinski otpad prevladava kamen, u sjeverozapadnom dijelu beton i opeka, a $\mathrm{u}$ istočnom opeka, odnosno miješani otpad (šuta).

Građevni otpad smatra se posebnom kategorijom otpada te se prema Pravilniku o katalogu otpada (NN 90/15) označava ključnim brojem 17.: Građevni otpad i otpad nastao od rušenja objekata (uključujući otpad od iskapanja onečišćenog tla). Podjela grupe 17 i njene podgrupe prikazane su u Tablici 1 .

Ovdje je važno istaknuti kako je po ukupnom volumenu i masi, relativna količina nastalog građevnog otpada najveća kod rušenja dotrajalih i / ili starih građevina. Tijekom tih aktivnosti od temeljne je važnosti pravilno i sustavno provođenje rušenja, a u cilju razdvajanja nastalog otpada na onaj koji se može i ne može ponovno iskoristiti, jer u protivnom gotovo $100 \%$ ruševnog materijala postaje otpad (Štirmer i sur., 2016). 
Tablica 1. Podjela grupe 17 i njene podgrupe (NN 90/15)

\begin{tabular}{|l|l|}
\hline 1700 & $\begin{array}{l}\text { Građevinski otpad i otpad od rušenja objekata (uključujući iskopanu zemlju s } \\
\text { onečišćenih lokacija) }\end{array}$ \\
\hline 1701 & beton, opeka, crijep / pločice i keramika \\
\hline 1702 & drvo, staklo i plastika \\
\hline 1702 & mješavina bitumena, ugljeni katran i proizvodi koji sadrže katran \\
\hline 1704 & metali (uključujući i njihove legure) \\
\hline 1705 & $\begin{array}{l}\text { zemlja (uključujući iskopanu zemlju s onečǐsćenih / kontaminiranih lokacija), } \\
\text { kamenje i iskop od rada bagera }\end{array}$ \\
\hline 1706 & izolacijski materijali i građevinski materijal koji sadrži azbest \\
\hline 1708 & građevinski materijal na bazi gipsa \\
\hline 1709 & ostali građevinski otpad i otpad od rušenja \\
\hline
\end{tabular}

\subsection{Količina gradevnog otpada}

Kako je navedeno u Odluci o donošenju Plana gospodarenja otpadom Republike $\mathrm{Hr}$ vatske za razdoblje 2017.-2022., procijenjena prosječna masa građevnog otpada u RH u razdoblju od 2001. do 2005. iznosila je 1,3 milijuna tona godišnje, a očekivani porast mase otpada u razdoblju od 2006. do 2015. iznosio je 2,3 milijuna tona godišnje. Podaci o građevnom otpadu određeni su temeljem prijava obrađivača otpada u bazu Registra onečišćenja okoliša (ROO). U 2014. prijavljena je masa od 761.312 tona građevnog otpada, od čega je gotovo $40 \%$ navedene mase zbrinuto postupkom odlaganja na odlagališta, najvećim dijelom zemlje i kamenja te miješanog građevnog otpada (NN 03/17). U Registar onečišćenja okoliša za 2017. podatke o građevnom otpadu prijavilo je ukupno 253 organizacijskih jedinica poduzeća u kojima je ukupno zaposleno 17.397 djelatnika (24\% od ukupnog broja zaposlenih u sektoru građevinarstva) (ROO, 2019). Ukupna masa građevnog otpada u 2017. procijenjena je na 1.225.263 tona. Najveće mase građevnog otpada pojavljuju se u Istarskoj (21\%), Zadarskoj županiji (16\%) te Gradu Zagrebu (14\%). U prve dvije županije razlog visokom udjelu velike su mase zemlje i kamenja (KB 7 - 170504) odložene na odlagališta, za koje su operateri odlagališta potvrdili da potječu isključivo s prostora tih dviju županija (HAOP, 2019).

Analiza Hrvatske agencije za okoliš i prirodu (2019), dala je pregled podataka o gospodarenju građevnim otpadom u 2017. u Republici Hrvatskoj (Tablica 2).

Kao što je prikazano u Tablici 2, zemlja, kamenje i otpad od jaružanja (podgrupa 17 $05)$ procijenjena je na $46 \%$ ukupne mase građevnog otpada. Miješani građevni otpad i otpad od rušenja objekata (podgrupa 1709 ) zastupljen je sa 20\%. Beton, cigle, crijep / pločice i keramika (podgrupa 1701 ) čine $14 \%$, a u toj grupi nerazvrstani miješani otpad čini čak 78\%. Metali i njihove legure (podgrupa 1704 ) u ukupnom građevnom otpadu čine $11 \%$, najviše se razvrstavaju i prijavljuju, pri čemu najveći udio u podgrupi čine željezo i čelik, čak $91 \%$. Ostale vrste otpada zastupljene su s manje od $6 \%$. 
Tablica 2. Struktura gradevnog otpada u 2017. (prema HAOP, 2019)

\begin{tabular}{|l|l|c|}
\hline 1700 & \multicolumn{1}{|c|}{ Građevinski otpad i otpad od rušenja objekata } & $\begin{array}{c}\text { Udio u ukupnom } \\
\text { građevnom otpadu }\end{array}$ \\
\hline 1701 & beton, opeka, crijep / pločice i keramika & $14 \%$ \\
\hline 1702 & drvo, staklo i plastika & $<6 \%$ \\
\hline 1702 & $\begin{array}{l}\text { mješavina bitumena, ugljeni katran i proizvodi koji sadrže } \\
\text { katran }\end{array}$ & $<6 \%$ \\
\hline 1704 & metali (uključujući i njihove legure) & $11 \%$ \\
\hline 1705 & $\begin{array}{l}\text { zemlja (uključujući iskopanu zemlju s onečišćenih / } \\
\text { kontaminiranih lokacija), kamenje i iskop od rada bagera }\end{array}$ & $46 \%$ \\
\hline 1706 & izolacijski materijali i građevinski materijal koji sadrži azbest & $<6 \%$ \\
\hline 1708 & građevinski materijal na bazi gipsa & $<6 \%$ \\
\hline 1709 & ostali građevinski otpad i otpad od rušenja & $20 \%$ \\
\hline
\end{tabular}

Podaci navedene analize pokazali su kako je mineralni građevni otpad, koji ima veliki potencijal za ponovnu uporabu i recikliranje, procijenjen na udio od $39 \%$ u ukupnom otpadu. Opasni otpad u građevnom otpadu procijenjen je na $1,8 \%$, od čega najviše onečišćenog tla, onečišćenih metala, plastike, drva i stakla (HAOP, 2019).

\section{GOSPODARENJE GRAĐEVNIM OTPADOM}

Izuzetno je važno urediti sustav gospodarenja otpadom u svakoj državi, jer neuređeni sustav ima negativan utjecaj na sve segmente okoliša (kao što su voda, zrak, more i tlo), te posljedično i na klimu, ljudsko zdravlje i drugi živi svijet. Osobito su ugrožene podzemne vode koje su glavni izvor zaliha pitke vode i temeljni nacionalni resurs. Kada je riječ o modelima gospodarenja otpadom postoje dva generalna pristupa: model koji optimizira i model kompenziranja (Morrissey i Browne, 2004). Model optimiziranja sugerira da se gubitak u jednom elementu kompenzira kroz dobitak u drugom, važnijem elementu, dok drugi model sugerira kako donositelj odluke nema sva potrebna znanja za adekvatnu odluku, ali je svjestan da se odluka mora donijeti iako joj je racionalnost ograničena.

U Hrvatskoj je gospodarenje otpadom definirano u Zakonu o održivom gospodarenju otpadom (NN 94/13), a znači skupljanje, prijevoz, oporaba i zbrinjavanje otpada uključujući nadzor nad tim postupcima i naknadno održavanje lokacija zbrinjavanja, a obuhvaća i radnje koje poduzimaju trgovac ili posrednik. Kod gospodarenja građevnim otpadom, važno je znati da različite vrste građevnog otpada imaju bitno različita svojstava, tako se npr. ne može na isti način tretirati otpad koji sadrži i ne sadrži opasne tvari i materijale poput azbesta, olova, katrana ili žive.

$\mathrm{Na}$ temelju obujma, otpad iz građevinarstva zauzima najveći udio u otpadu u EU. Zato Europska komisija uvodi novi protokol o gradnji i rušenju (Europska komisija, 2019d). 
$\mathrm{Na}$ temelju neovisnog istraživanja, uvodi neobvezujuće smjernice kao prijedlog industriji. Ovaj se protokol uklapa u strategiju izgradnje 2020., kao i u Komunikaciju o mogućnostima za učinkovitu upotrebu resursa u građevinskom sektoru. Također je dio ambicioznog i nedavno usvojenog Paketa o kružnom gospodarstvu Europske komisije. Njegov je opći cilj povećati povjerenje u proces upravljanja otpadom u građevinarstvu i rušenje i povjerenje u kvalitetu recikliranih materijala za građevinarstvo i rušenje. Protokol je razvijen za primjenu u svih 28 zemalja EU.

Pravilno upravljanje građevnim otpadom i recikliranim materijalima - uključujući ispravno rukovanje opasnim otpadom - može imati velike prednosti u smislu održivosti i kvalitete života. Ali ona također može pružiti velike koristi za građevinsku i reciklažnu industriju u EU-u, jer potiče potražnju za recikliranim materijalima. Okvirna direktiva o otpadu 2008/98 / EC imala je za cilj da se do 2020. reciklira 70\% građevnog otpada i otpada od rušenja. Rezultati koji se trenutno prikupljaju i obrađuju tek će pokazati je li i u kojoj mjeri ovaj cilj ostvaren.

\subsection{Plan gospodarenja gradevnim otpadom $u R H$}

U Hrvatskoj je 2017. donesen Plan gospodarenja otpadom RH za razdoblje 2017-2022. (NN 03/17). Cilj je sustava gospodarenja građevnim otpadom do 1. siječnja 2020. putem nadležnih tijela osigurati pripremu za ponovnu uporabu, recikliranje i druge načine materijalne oporabe, uključujući postupke zatrpavanja i nasipavanja, u kojima se otpad koristi kao zamjena za druge materijale, neopasnog građevnog otpada, isključujući materijal iz prirode utvrđen ključnim brojem 170504 - zemlja i kamenje koji nisu navedeni pod 1705 03, u minimalnom udjelu od 70\% mase otpada (NN 94/13). Prema Pravilniku o registru onečišćavanja okoliša (NN 87/15), obveznik dostave podataka dužan je nadležnom tijelu dostaviti podatke o nastanku i / ili prijenosu izvan mjesta nastanka:

- opasnog otpada u ukupnoj masi većoj od ili jednakoj 0,5 tona godišnje;

- neopasnog otpada u ukupnoj masi većoj od ili jednakoj 20 tona godišnje.

Prema Pravilniku o građevnom otpadu i otpadu koji sadrži azbest (NN 69/16), posjednik građevnog otpada dužan je, na gradilištu na kojem je nastao taj otpad, izdvojiti od drugog otpada i materijala koji nije otpad te odvojeno skladištiti neopasni otpad koji čini najmanje $80 \%$ mase svog otpada nastalog na određenom gradilištu, osim ako obvezu izdvajanja tog otpada razvrstavanjem i drugim odgovarajućim tehnološkim procesima gospodarenja otpadom izvrši osoba, koja posjeduje odgovarajuću dozvolu za gospodarenje otpadom, na temelju ugovora s posjednikom ili vlasnikom građevnog otpada.

Nadzor nad provedbom Plana obavlja Ministarstvo zaštite okoliša i energetike (MZOE) koje je dužno, jednom godišnje, podnositi Vladi RH izvješće o izvršenju utvrđenih obveza i učinkovitosti poduzetih mjera iz Plana. Vremenski plan uspostavljanja cjelovitog sustava gospodarenja otpadom u RH bio je sljedeći: u 2017. potrebno je napraviti akcijski plan za odvojeno prikupljanje i recikliranje građevnog otpada; u razdoblju od 
2017. do 2020. predviđena je izgradnja postrojenja za sortiranje odvojeno prikupljenog papira, kartona, metala, stakla, plastika i dr. (sortirnica); za razdoblje od 2017. do 2022. potrebno je uspostaviti županijske i regionalne centre za gospodarenje otpadom.

\subsection{Problemi pri gospodarenju gradevnim otpadom}

Iz svega navedenog mogu se definirati ključni problemi u području gospodarenja gradevnim otpadom, a to su:

- nije uspostavljena kvalitetna i transparentna komunikacija između svih dionika u procesu gospodarenja građevnim otpadom;

- ne postoji kvalitetna evidencija izvora, količina i tijekova građevnog otpada iako za istu postoji zakonski okvir (ali se nažalost ne primjenjuje);

- masa građevnog otpada prilično je velika i stalno se nekontrolirano odlaže na „divlja" odlagališta;

- ne postoji sustav odvajanja građevnog otpada na mjestu nastajanja;

- sustavno se ne izdvaja opasan otpad i otpad onečišćen opasnim tvarima iz građevnog otpada;

- ekonomski se ne potiče korištenje takozvanih zelenih materijala koji su prihvatljiviji za okoliš;

- u svima se fazama izgradnje objekata problem građevnog otpada često marginalizira;

- ne postoji razrađen sustav poticanja korištenja i normizacije recikliranih materijala;

- nepostojanje jedinstvenog provedbenog propisa kojim bi se uredilo postupanje $s$ građevnim otpadom te jasno odredila prava i obveze sudionika u sustavu gospodarenja građevnim otpadom.

Također, unatoč postojanju službenih odlagališta na području gradova, županija pa i države, građevni otpad često se nelegalno odlaže na više lokacija. Tzv. divlja odlagališta otpada manji su neuređeni prostori koji nisu predviđeni za odlaganje otpada, a formirali su ih najčešće građani bez prethodnog znanja tijela lokalne samouprave. Ne raspolažu nikakvim dokumentima relevantnim za njihovo djelovanje, a otpad uglavnom individualno, dovoze građani.

Na područjima na kojima se nekontrolirano odlaže otpad i na kojima se isti duže zadržava može doći do pojave raznih neželjenih utjecaja kao što su onečišćenje tla, onečišćenje podzemnih i površinskih voda procjednim vodama, onečišćenje zraka uzrokovano izbijanjem požara i sl. Također, javljaju se i ekonomske posljedice stvaranja takvih odlagališta koje uključuju smanjenu vrijednost nekretnina te porast poreza i prireza zajednice radi troškova sanacije odlagališta, a zbog smanjene atraktivnosti prostora (lokaliteta) za život, posljedično se narušava i demografska struktura.

Planom gospodarenja otpadom RH za razdoblje 2017.-2022. (NN 03/17) planiraju se zatvaranja odlagališta neopasnog otpada koja će uključivati i analizu za daljnje kapacitete i mogućnosti za odlaganje otpada na usklađenim odlagalištima otpada. 


\section{KRUŽNA EKONOMIJA - OD SMEĆA DO BOGATSTVA}

Naš trenutni ekonomski model, proizvodni, ljudski i prirodni kapitali svi su u funkciji blagostanja podržavajući nekontroliranu proizvodnju roba i usluga. Primarni je razlog za rastući interes za koncept kružne ekonomije kapacitet današnjih poslovnih modela da integriraju zaštitu okoliša, razvoj društva i ekonomski prosperitet i to sve u jedinstvenom, koherentnom i modelu koji potiče na akciju za održivi razvoj (Tonelli i Cristoni, 2019). Kružna ekonomija predstavlja strateški koncept prelaska s postojećeg linearnoga gospodarstva koje kreira smeće na kružno gospodarstvo koje minimizira negativni utjecaj čovjeka na okoliš. Kružna ekonomija novi je ekonomski model koji bi trebao postati globalni cilj svakog gospodarstva. U literaturi postoje mnoge definicije ovog koncepta. Prema Fosteru (2020), kružna je ekonomija proces proizvodnje i potrošnje koji zahtijevaju minimalno korištenje prirodnih resursa i minimalni utjecaj na okoliš produžujući upotrebu materijala te smanjujući potrošnju i otpad materijala i energije.

Osnovna je pretpostavka kružne ekonomije održivost u smislu produženja životnog vijeka raznih proizvoda i osiguranje većeg stupnja gospodarenja resursima s ciljem smanjenja otpada. Osigurava održivo gospodarenje resursima, produženje životnog vijeka proizvoda s ciljem smanjenja otpada te povećanu uporabu obnovljivih izvora energije. Za razliku od linearnog gospodarstva, ovo je poslovni koncept u kojem se tokovi resursa i energije održavaju u modelu zatvorene petlje, $s$ namjerom da proizvodi što duže cirkuliraju u kružnom ciklusu i da po mogućnosti iz njega ne izlaze (Brears, 2018). Naglasak je na proizvodnji i dizajniranju proizvoda koji se mogu relativno jednostavno i lagano rastaviti na dijelove te ponovno upotrijebiti; koji neće sadržati opasne materije štetne za čovjeka i okoliš; te koji će biti bitno dužeg životnog vijeka i po potrebi lako popravljivi. Dakle, otpad i korištenje resursa pokušava se minimizirati, a kada proizvod dosegne kraj svog životnog vijeka pokušava se u cijelosti iskoristiti za stvaranje nove vrijednosti. U Europskoj uniji prepoznali su važnost ovog koncepta jer potiče inovacije, generira održivost poslovnih modela i rezultira kreacijom novih radnih mjesta (Europska komisija, 2019a). Tako je prema istom izvoru 2. prosinca 2015. donesen paket koji se sastojao od niza mjera koje su obuhvaćene sa 54 aktivnosti, a koje bi trebale potaknuti tranziciju europskog gospodarstva iz linearnog u kružno. Pretpostavka je da prihvaćanje koncepta kružne ekonomije doprinosi konkurentnosti, ne samo pojedinih poduzeća, već i država u cjelini. Europska je komisija nedavno objavila novi Akcijski plan cirkularne ekonomije (A new Circular Economy Action Plan) kojim najavljuje nove inicijative tijekom cijelog životnog ciklusa proizvoda, usmjerenih npr. na njihov dizajn, promicanje procesa kružne ekonomije, poticanje održive potrošnje. Novi Plan ima za cilj i zadržavanje korištenih resursa u gospodarstvu Europske unije što je dulje moguće (Europska komisija, 2020). Gospodarenje otpadom jedna je od najvažnijih komponenti cirkularne ekonomije. Kada je Europska unija još 1975. po prvi puta predstavila hijerarhiju otpada, mnoge su je države preuzele i krenule u razvoj dugoročne strategije vođenja sektora otpada (Williams, 2015). Od tada su veliki napori napravljeni upravo u istraživanju i analizi mogućnosti ponovne uporabe građevnog otpada. Razlika između gospodarenja otpadom 
i kružne ekonomije je ta što je hijerarhija gospodarenja otpadom definirana za EU još uvijek usredotočena na otpad nakon konzumacije, za razliku od kružne ekonomije kojoj je cilj postizanje „recirkulacije“ resursa kroz nove proizvode i novi dizajn sustava (Singh i Ordonez, 2016). S obzirom na veliki utjecaj građevinskog sektora u svakoj nacionalnoj ekonomiji, kojeg između ostalog karakterizira upotreba velike količine materijala, opravdano je korištenje koncepta kružne ekonomije upravo u ovoj djelatnosti.

\section{ANALIZA GOSPODARENJA GRAĐEVNIM OTPADOM U RH}

Kao što je već prethodno u radu navedeno, Plan gospodarenja otpadom u Republici Hrvatskoj temeljni je dokument o gospodarenju otpadom u Republici Hrvatskoj za razdoblje od 2017.-2022. (NN 03/17) te je izrađen na temelju Strategije gospodarenja otpadom Republike Hrvatske, postojećih zakonskih propisa i smjernica Europske unije. Na temelju istraživanja Građevinskog fakulteta u Zagrebu 2017. (HAOP, 2019), procijenjena ukupna masa građevnog otpada u 2015. iznosila je 1.189.316 tona. Na Slici 1 prikazana je struktura građevinskih poduzeća (prema veličini) koja su u 2015. zbrinula građevni otpad (Slika 1).

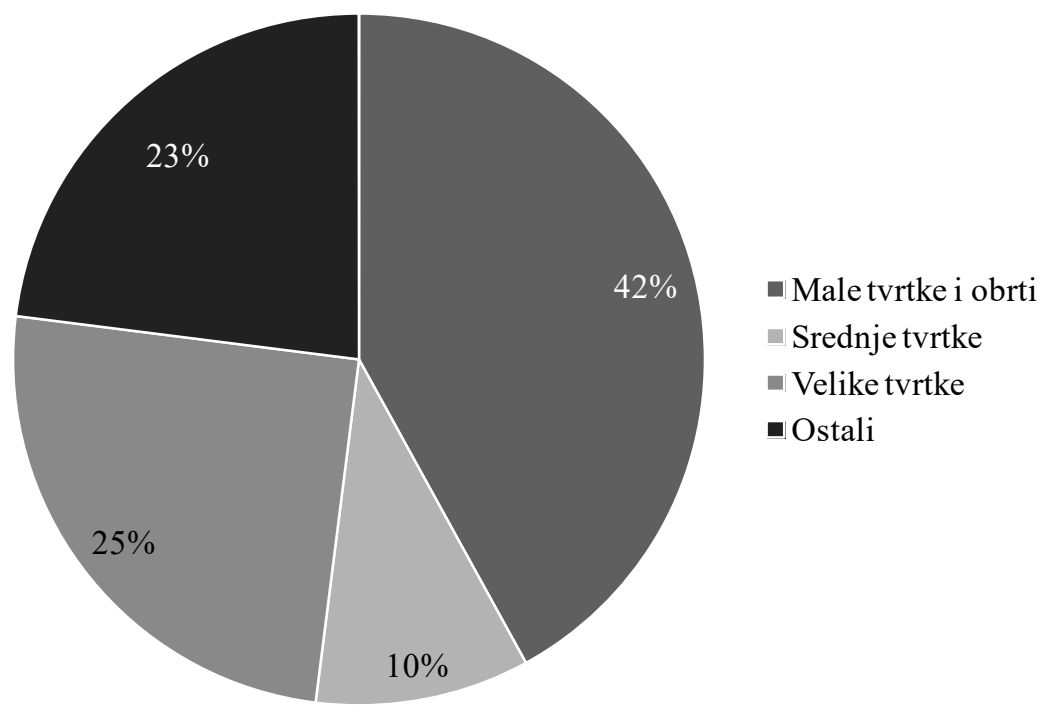

Slika 1. Udio procijenjene mase gradevnog otpada prema veličini poduzeća / obrta s glavnom djelatnoš́u F gradevinarstvo

Prema podacima najveći udio mase građevnog otpada zbrinjavaju mala poduzeća i obrti s postotkom od $42 \%$, zatim $25 \%$ odlazi na velika poduzeća, $23 \%$ na ostale, a na srednja poduzeća $10 \%$.

U Tablici 2 prikazana je procijenjena količina građevnog otpada prema ključnim brojevima i ovisno o veličini poduzeća / obrta (Štirmer i Škreb, 2017). 
Tablica 3. Procijenjena masa gradevnog otpada po ključnim brojevima ovisno o veličini poduzeća / obrta (Štirmer i Škreb, 2017)

\begin{tabular}{|c|c|c|c|c|c|}
\hline Ključni broj & $\begin{array}{c}\text { Velika } \\
\text { poduzeća } \\
\text { (tona) }\end{array}$ & $\begin{array}{c}\text { Srednja } \\
\text { poduzeća } \\
\text { (tona) }\end{array}$ & $\begin{array}{c}\text { Mala } \\
\text { poduzeća } \\
\text { (tona) }\end{array}$ & \begin{tabular}{|c|} 
Ostali (podaci \\
iz ROO) \\
(tona)
\end{tabular} & $\begin{array}{c}\text { Ukupno } \\
\text { (tona) }\end{array}$ \\
\hline 170101 & $12.492,81$ & $5.983,57$ & $10.948,26$ & $4.448,24$ & $33.872,88$ \\
\hline 170102 & 7,86 & & 958,79 & $1.970,37$ & $2.937,02$ \\
\hline 170103 & 18,79 & & 33,64 & 307,76 & 360,19 \\
\hline 170107 & $2.782,94$ & $75.744,13$ & $33.413,54$ & $5.814,00$ & $117.754,76$ \\
\hline 170201 & $1.076,10$ & 11,83 & 172,36 & 870,73 & $2.131,02$ \\
\hline 170202 & & 74,47 & 393,61 & $2.296,65$ & $2.764,73$ \\
\hline 170203 & 39,5 & 9,6 & 3,36 & 414,44 & 466,90 \\
\hline $170204^{*}$ & 785,71 & 259,23 & 124,25 & $2.561,54$ & $3.730,73$ \\
\hline $170301^{*}$ & 5,57 & 4,57 & & 2,65 & 12,79 \\
\hline 170302 & $9.296,65$ & $2.330,94$ & $6.587,05$ & $23.326,59$ & $41.541,23$ \\
\hline 170303 & 0,22 & & & 0,07 & 0,29 \\
\hline 1704 (nerazvrstan) & & & 560,7 & & 560,7 \\
\hline 170401 & 0,17 & 0,07 & 3,36 & $2.346,72$ & $2.368,23$ \\
\hline 170402 & 66,75 & 36,91 & 57,25 & $3.105,32$ & $3.266,23$ \\
\hline 170403 & & & & 152,99 & 152,99 \\
\hline 170404 & & 2,02 & & 54,09 & 56,11 \\
\hline 170405 & 2978,6 & $1.395,12$ & 9490.36 & $67.825,27$ & $81.689,35$ \\
\hline 170406 & & & & 1,96 & 1,96 \\
\hline 170407 & 3,9 & 517,41 & 247,73 & $1.760,27$ & $2.519,31$ \\
\hline $170409^{*}$ & & & & 616,67 & 616,67 \\
\hline $170410^{*}$ & 34,5 & & & 184,91 & 219,41 \\
\hline 170411 & 4,57 & 3,98 & 4,09 & 994,53 & $1.07,17$ \\
\hline 1705 (nerazvrstan) & $133.524,29$ & $2.927,88$ & $74.067,91$ & & $210.520,08$ \\
\hline $170503^{*}$ & 2,93 & & & $12.233,37$ & $12.236,30$ \\
\hline 170504 & $134.311,12$ & $3.111,10$ & $168.529,79$ & $36.648,63$ & $342.620,64$ \\
\hline $170505^{*}$ & & & & $2.798,32$ & $2.798,32$ \\
\hline 170506 & & 721,27 & $12.178,31$ & $4.267,41$ & $17.166,99$ \\
\hline $170507^{*}$ & & & & 0,24 & 0,24 \\
\hline 1706 (nerazvrstan) & 1,57 & 24,23 & 105,86 & & 131,66 \\
\hline $170601^{*}$ & & 10,1 & & 30,21 & 40,31 \\
\hline $170603^{*}$ & 2,88 & 1,56 & & 23,54 & 27,98 \\
\hline 170604 & 22,32 & 168,69 & 435,49 & 414,7 & $1.041,20$ \\
\hline $170605^{*}$ & 12,7 & 404,17 & 100,48 & 487,78 & $1.015,13$ \\
\hline 1708 (nerazvrstan) & 12,07 & & 504,63 & & 516,70 \\
\hline 170802 & 5,28 & & 482,2 & 265,16 & 752,64 \\
\hline 1709 (nerazvrstan) & & $3.814,33$ & $69.206,68$ & & $73.021,01$ \\
\hline
\end{tabular}




\begin{tabular}{|l|c|c|c|c|c|}
\hline $170903^{*}$ & & 54,49 & & 8,24 & 62,73 \\
\hline 170904 & $3.282,53$ & $15.152,49$ & $11.562,67$ & $93.237,36$ & $123.235,05$ \\
\hline Nerazurstani & & $4.562,69$ & 101.535 .98 & & $106.098,67$ \\
\hline \multicolumn{1}{|c|}{ Ukupno } & $\mathbf{3 0 0 . 7 9 2 , 2 3}$ & $\mathbf{1 1 7 . 3 2 6 , 8 5}$ & $\mathbf{5 0 1 . 6 9 8 , 3 5}$ & $\mathbf{2 6 9 . 4 9 8 , 7 3}$ & $\mathbf{1 . 1 8 9 . 3 1 6 , 2 6}$ \\
\hline
\end{tabular}

U prikazanoj tablici masa otpada koju zbrinjavaju velika poduzeća iznosi 300.792,23 tona, srednja poduzeća 117.326,85 tona, dok ukupan iznos koji zbrinjavaju mala poduzeća iznosi 501.698,35 tona ili 42\%.

Kako bi se ostvario jedan od ciljeva ovog članka, dobiti informacije o gospodarenju otpadom u građevinskoj industriji, provedeno je istraživanje putem intervjua u četiri velika poduzeća koja se bave zbrinjavanjem papira, kartona, stakla, azbesta, metala i građevnog otpada. Odabrana su 4 velika poduzeća koja su registrirana u području E: Opskrba vodom, uklanjanje otpadnih voda, gospodarenje otpadom te djelatnost sanacije okoliša Ispitanici su odgovarali na pitanja koja su se odnosila na zbrinjavanje i gospodarenje građevnim otpadom.

\subsection{Rezultati provedenog istraživanja}

Poduzeća koja su ušla u ovo istraživanje odabrana su s obzirom na lokaciju (okolica Zagreba i grad Zagreb) radi lakše dostupnosti ispitanika. Poduzeća koja se u Hrvatskoj bave zbrinjavanjem otpada, prema NKD 2007 svrstana su u područje E: Opskrba vodom, uklanjanje otpadnih voda, gospodarenje otpadom te djelatnost sanacije okoliša, razred 38: Skupljanje otpada, djelatnost obrade i zbrinjavanje otpada, oporaba materijala (NN 58/07). Sva intervjuirana poduzeća registrirana su za djelatnost sakupljanja određene vrste građevnog otpada (šuta), kao i dodatnih vrsta otpada - staklo, papir, knauf i izolacijski materijal.

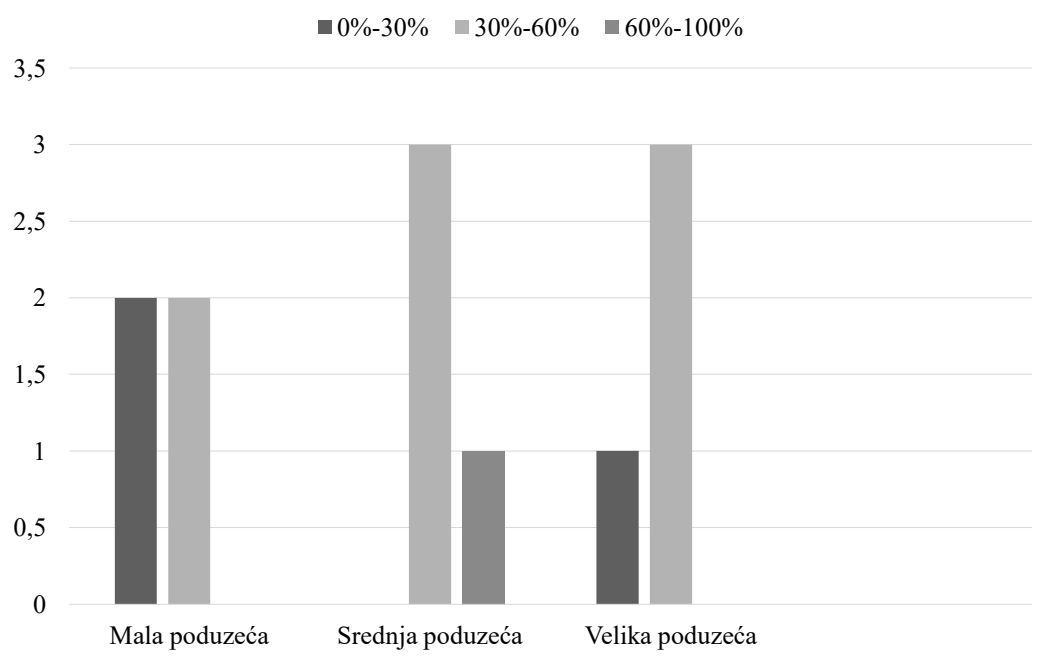

Slika 2. Udio primljenog gradevnog otpada od poduzeća razvrstanih prema veličini 
Kod svih ispitanih poduzeća udio građevnog otpada u ukupnom sakupljenom otpadu iznosi između $20 \%$ i $50 \%$. Najveća masa građevnog otpada zaprimljena je od srednjih i velikih građevinskih poduzeća (Slika 2).

Iz Slike 2 može se vidjeti kako je kod ispitanih poduzeća najveći udio otpada zaprimljen od srednjih i velikih građevinskih poduzeća. Prema dobivenim odgovorima, dva poduzeća su odgovorila kako su zaprimila do $30 \%$ otpada od malih poduzeća, a ostala dva poduzeća odgovorila su da su zaprimila između $30 \%$ i $60 \%$ otpada od malih poduzeća. Od četiri ispitana poduzeća, tri su poduzeća zaprimila otpad od srednjih poduzeća u udjelu od 30\% i 60\%, dok je jedno poduzeće odgovorilo da je udio otpada zaprimljen od srednjih poduzeća između $60 \%$ i $100 \%$. Od velikih poduzeća jedno je poduzeće zaprimilo do $30 \%$ otpada, dok su ostala poduzeća zaprimila između $30 \%$ i $60 \%$ otpada od velikih poduzeća.

$\mathrm{Na}$ pitanje vrše li recikliranje prikupljenog otpada, samo je jedno poduzeće odgovorilo negativno. Temeljem pitanja o izvozu građevnog otpada, sva ispitana poduzeća izvoze određeni dio otpada. U 2018., ispitana poduzeća zajedno su izvezla oko 53\% sakupljenog građevnog otpada. Zemlje u koje se najviše izvozi građevni otpad iz Hrvatske su: Austrija, Mađarska, Njemačka, Slovenija, Srbija, Italija, Španjolska i Nizozemska.

\section{ZAKLJUČAK}

$S$ jedne strane količina koja se mjeri ukupnom masom otpada jedan je od izravnih pokazatelja razvijenosti svijesti određenog društva, dok je $s$ druge strane jedan od ključnih ciljeva europskih politika u vezi s održivosti, kružnom ekonomijom i utjecajem na okoliš pretvaranje otpada u resurs. Koncept kružnog gospodarstva polazi od pretpostavke zamjene linearnih dugoročno održivim sustavima koji neće uništavati, već održavati resurse dostupnima za iduće generacije. Sustavi bi trebali funkcionirati tako da je povratak proizvoda, tvari i materijala u gospodarstvo te njihova ponovna uporaba učinkovita i univerzalno primjenjiva. Upravo bi građevinska industrija ovaj koncept trebala razvijati $s$ obzirom na veliku masu korištenja različitih materijala u različitim fazama građevinskog procesa. Građevni otpad koji nastaje u tom procesu većinom je neopasan i / ili inertan otpad (oko 95\%), dok je ostali građevni otpad (koji najčešće sadrži azbest) opasan i ako se neadekvatno tretira može imati štetne posljedice na ljudsko zdravlje i okoliš. Primjenjujući neke elemente DOP-a (posebno one koji su u vezi sa zaštitom okoliša) poduzeća mogu u fazi planiranja izbjeći negativne i neželjene posljedice za okoliš i društvo, ali isto tako smanjiti vlastite rizike poslovanja.

DOP bi se trebao implementirati u poslovnu strategiju gotovo svakog poduzeća (posebno onih sa značajnim utjecajem), gdje bi se uporabom ljudskih potencijala te korištenjem njihovog intelekta mogla odgovorno primjenjivati tehnologija zaštite okoliša i održive izgradnje zajednice koja ga okružuje. U tom smislu povjerenje se treba zaraditi, a ne da ga menadžment očekuje. Izradom ovoga rada kao i analizom pronađenih podataka i informacija, može se zaključiti kako se svijest o brizi za okoliš, kao i strateška implementacija DOP-a te svijest o potrebi adekvatnog zbrinjavanja i gospodarenja ot- 
padom iz godinu u godinu poboljšava u Republici Hrvatskoj. Činimo li to dovoljno brzo i učinkovito drugo je pitanje.

Gospodarenje otpadom izaziva u javnosti sve više pozornosti, posebno zbog sve prisutnijih divljih odlagališta koja imaju direktni i indirektni negativni utjecaj na lokalnu zajednicu. U Hrvatskoj jesu učinjeni pozitivni pomaci, ali ti pomaci nisu dovoljni niti s njima možemo biti apsolutno zadovoljni. Prije nego što je Hrvatska postala punopravna članica Europske unije, donijela je Plan gospodarenja otpadom za razdoblje 2007.2015. Njime se obvezala na vremenski plan uspostavljanja cjelovitog sustava gospodarenja otpadom u RH, koji nije velikim dijelom ispoštovan. U siječnju 2017., na snagu je stupio novi Plan gospodarenja otpadom Republike Hrvatske za razdoblje 2017.-2022. za koji se također do sada može zaključiti kako u nekim ključnim elementima njegove provedbe ne postoji koordinirano i sustavno djelovanje ključnih dionika te samim time niti njegov učinak ne može biti potpun.

Činjenica jest kako se veći dio građevnog otpada može reciklirati. Republika Hrvatska, kao što je ranije navedeno, sukladno zakonskoj regulativi EU do 2020. minimalno $70 \%$ građevnog otpada morat će reciklirati, što uključuje recikliranje i druge vrste uporabe otpada u korisne svrhe. Prema podacima iz 2017., tek se 53\% građevnog otpada recikliralo. U trenutku pisanja ovog članka malo je vjerojatno kako će se ovaj cilj (od 70\%) ostvariti. Radi se o pitanju koje je u nadležnosti nekoliko različitih ministarstva, stoga se svi trebaju povezati i snažnije koordinirati kako bi se amortizirale negativne posljedice koje će nastati nakon što postane jasno kako se ovaj cilj nažalost nije ostvario. Mišljenja smo kako veliki dio problema leži u nedovoljnoj svjesnosti ključnih dionika u važnosti sustavnog djelovanja. Prema registru dozvola i potvrda za gospodarenje otpadom 300 poduzeća ima dozvolu za gospodarenje, a 170 za postupak oporabe. Jedan od važnih elemenata kako bi se čim veći postotak građevnog otpada ponovno koristio predstavlja uspostava regionalnih reciklažnih dvorišta kao i uspostava tržišta otpadnog materijala. Dodatno bi se situacija mogla poboljšati i poticanjem selektivnog rušenja ali to se izbjegava jer zahtijeva vrijeme, financijske i ljudske resurse.

Sustavno se posljednjih godina pojavljuju najave o moguće plaćanju kazni prema EU i to upravo zbog neodgovornog postupanja s otpadom, no represija može riješiti tek dio problema. Pozitivno je što Europska unija provodi niz mjera kojima potiče izgradnju reciklažnih dvorišta i gospodarskih centara za gospodarenje otpadom, kao i poticanje zelene gradnje same države. Međutim, glavni je problem RH što se propisi gospodarenja otpadom ne provode u cijelosti.

Iz svega napisanoga, proizlaze mnoge nove mogućnosti i smjerovi za buduća istraživanja u području upravljanja građevnim otpadom. Posebno bi bilo korisno istražiti na koji način upravo mala i srednja građevinska poduzeća u Hrvatskoj upravljaju i razvijaju strategiju DOP-a i korištenje i zbrinjavanje upravo građevnog otpada koji sami proizvode. Naime, činjenica je da je cijela procedura oko zbrinjavanja građevnog otpada vrlo složena, i samim time generira dodatne troškove, pogotovo u kontekstu malih poduzeća. Također, iznimno bi bilo važno istražiti zašto i gdje nastaje razlika između prijavljene količine građevnog otpada i količine koja je preuzeta. 


\section{LITERATURA}

Awan, U., Khattak, A. i Kraslawski, A. (2019). Corporate Social Responsibility (CSR) Priorities in the Small and Medium Enterprises (SMEs) of the Industrial Sector of Sialkot. U: Golinska-Dawson, P. i Spychała, M. (ur.), Corporate Social Responsibility in the Manufacturing and Services Sectors (str. 267-280). Cham: Springer.

Bačun, D., Matešić, M. i Omazić, M. A. (2012). Leksikon održivog razvoja. Zagreb: Hrvatski poslovni savjet za održivi razvoj.

Baumann-Pauly, D., Wickert, C. Spence, L. i Scherer, A. (2013). Organizing Corporate Social Responsibility in Small and Large Firms: Size Matters. Journal of Business Ethics, 115(4): 693-705.

Brears, R. C. (2018). Natural Resource Management and the Circular Economy. Cham: Palgrave Macmillan.

Building Radar (2020). 20 construction industry trends to watch in 2020. Building Radar, 14. siječnja 2020. URL: https://buildingradar.com/construction-blog/construction-industry-trends/ (15.05.2020.)

Carroll, A. B. (2015). Corporate social responsibility: The centerpiece of competing and complimentary frameworks. Organizational Dynamics, 44(2): 87-96.

Ciliberti, F., Pontrandolfo, P. i Scozzi, B. (2008). Investigating corporate social responsibility in supply chains: a SME perspective. Journal of Cleaner Production, 16(15): 1579-1588.

Clark, D. (2019). Number of small and medium-sized enterprises (SMEs) the European Union in 2018. Statista. URL: https:/www.statista.com/statistics/878412/ number-of-smes-in-europe-by-size (24.05.2020.)

De Angelis, R. (2018). Business Models in the Circular Economy - Concepts, Examples and Theory. Cham: Springer International Publishing.

Del Baldo, M. (2018). Integrated Reporting in Small and Medium Enterprises: Issues and Perspectives from Italy. U: Idowu, S. O., Sitnikov, C., Simion, D. i Bocean, C. G. (ur.), Current Issues in Corporate Social Responsibility - An International Consideration (str. 195-216). Cham: Springer.

Deloitte (2020). 2020 Engineering and Construction Industry Outlook. London: Deloitte. URL: https://www2.deloitte.com/content/dam/Deloitte/us/Documents/energyresources/2020-engineering-construction-industry-outlook.pdf (15.05.2020.)

Državni zavod za statistiku (DZS) (2020). Broj i struktura poslovnih subjektata u prosincu 2019. Priopćenje, 56 (11.1.1/4.). URL: https://www.dzs.hr/Hrv_Eng/publication/2019/11-01-01_04_2019.htm (12.3.2020.)

Europska komisija (2019a). Circular Economy. URL: https:/ec.europa.eu/growth/industry/sustainability/circular-economy_hr (24.11.2019.)

Europska komisija (2019b). Commission Staff Working document - Corporate Social Responsibility, Responsible Business Conduct, and Business and Human Rights: Overview of Progress. SWD(2019) 143 final, Bruxelles, 20. ožujka 2019. URL: https://ec.europa.eu/docsroom/documents/34482/attachments/1/translations/en/ renditions/native (28.04.2020.) 
Europska komisija (2019c). Corporate Social Responsibility \& Responsible Business Conduct. URL: https://ec.europa.eu/growth/industry/sustainability/corporate-social-responsibility_hr (24.11.2019.)

Europska komisija (2019d). Waste. URL: http://ec.europa.eu/environment/waste/index.htm (25.11.2019.)

Europska komisija (2020). Komunikacija Komisije Europskom parlamentu, Vijeću, Europskom gospodarskom i socijalnom odboru i Odboru regija - Novi akcijski plan za kružno gospodarstvo za čišću i konkurentniju Europu. COM(2020) 98 final, Bruxelles, 11. ožujka 2020. URL: https://eur-lex.europa.eu/resource.html?uri=ce llar:9903b325-6388-11ea-b735-01aa75ed71a1.0014.02/DOC_1\&format=PDF (28. 4. 2020.)

Foster, G. (2020). Circular economy strategies for adaptive reuse of cultural heritage buildings to reduce environmental impacts. Resources, Conservation and Recycling, 152: 1-14. DOI: 10.1016/j.resconrec.2019.104507

Hrvatska agencija za okoliš i prirodu (HAOP) (2019). Pregled podataka o gospodarenju građevnim otpadom u 2017. godini. Zagreb: HAOP. URL: http://www.haop.hr/sites/default/files/uploads/dokumenti/021_otpad/Izvjesca/ostalo/OTP_ZA_WEB_ Pregled\%20podataka\%20o\%20gospodarenju\%20gradjevnim\%20otpadom $\% 20$ u\%202017\%20godini.pdf (22. 11. 2019.)

Jamali, D., Zanhour, M. i Keshishian, T. (2009). Peculiar strengths and relational attributes of SMEs in the context of CSR. Journal of Business Ethics, 87(3): 355-367.

Jenkins, H. (2004). A critique of conventional CSR theory: An SME perspective. Journal of General Management, 29(4): 37-57.

Jenkins, H. (2006). Small business champions for corporate social responsibility. Journal of Business Ethics, 67(3): 241-256.

Khanka, S. S. (2014). Business Ethics and Corporate Social Responsibility. New Delhi: S. Chand \& Company PVT.

Midttun, A. (2013). CSR and Business Strategy. U: Midttun, A. (ur.), CSR and Beyond - A Nordic Perspective (str. 23-27). Oslo: Cappelen Damm AS.

Matten, D. i Moon, J. (2008). Implicit and explicit CSR: A conceptual framework for a comparative understanding of corporate social responsibility. Academy of Management Review, 33(2): 404-424.

Morrissey, A. J. i Browne, J. (2004). Waste management models and their application to sustainable waste management. Waste Management, 24(3): 297-308.

Murillo, D. i Lozano, J. M. (2006). SMEs and CSR: An Approach to CSR in their Own Words. Journal of Business Ethics, 67(3): 227-240.

Nacionalna klasifikacija djelatnosti 2007. Narodne novine, 58/07.

Odluka o donošenju Plana gospodarenja otpadom Republike Hrvatske za razdoblje 2017.-2022. godine. Narodne novine, 03/17.

Omazić, M. A. (2008). Društvena odgovornost poduzeća i korporativno upravljanje. U: Tipurić, D. (ur.), Korporativno upravljanje (str. 323-360). Zagreb: Sinergija nakladništvo. 
Owen, D. i O'Dwyer, B. (2008). Corporate Social Responsibility: The Reporting and Assurance Dimension. U: Crane, A., McWilliams, A., Matten, D., Moon, J. i Stegel, D. S. (ur.), The Oxford Handbook of Corporate Social Responsibility (str. 384413). New York: Oxford University Press.

Perrini, F. (2006). SMEs and CSR Theory, Evidence and Implications from an Italian Perspective. Journal of Business Ethics, 67(3): 305-316.

Plan gospodarenja otpadom u RH za razdoblje 2007.-2015. godine. Narodne novine, br. $85 / 07$

Pravilnik o građevnom otpadu i otpadu koji sadrži azbest. Narodne novine, 69/16.

Pravilnik o katalogu otpada. Narodne novine, 90/15.

Pravilnik o registru onečišćavanja okoliša. Narodne novine, 87/15.

Rasche, A., Morsing, M. i Moon, J. (ur.) Corporate Social Responsibility - Strategy, Communication, Governance. Cambridge: Cambridge University Press.

Registar onečišćavanja okoliša (ROO) (2019) Preglednik registra onečišćavanja okoliša. URL: http://roo.azo.hr/rpt.html?rpt=no\&pbl=roo ttp://roo.azo.hr/index.html (23.11.2019.)

Russo, A. i Tencati, A. (2009). Formal vs. informal CSR strategies: Evidence from Italian micro, small, medium-sized, and large firms. Journal of Business Ethics, 85: 339-353.

Singh, J. i Ordonez, I. (2016). Resource recovery from post-consumer waste: important lessons for the upcoming circular economy, Journal of Cleaner Production, 134: 342-353.

Štirmer, N., Baričević, A. i Škreb, K. A. (2016). Poboljšanje toka i kvalitete podataka o građevnom otpadu i otpadu od istraživanja i eksploatacije mineralnih tvari u Republici Hrvatskoj. Poboljšanje toka i kvalitete podataka o gradevnom otpadu i otpadu od istraživanja i eksploatacije mineralnih tvari u Republici Hrvatskoj, Aktivnost 1.2. HAOP i Građevinski fakultet Sveučilišta u Zagrebu.

Štirmer, N., Baričević, A. i Lovinčić Milovanović, V. (2017). Gospodarenje građevnim otpadom - izazovi i prilike. U: Lakušić, S. (ur.), Izazovi u graditeljstvu 4 (str. 176200). Zagreb: Hrvatski savez građevinskih inženjera.

Štirmer, N. i Škreb, K. A. (2017). Procjena količina građevnog otpada i potencijala za njegovo korišstenje. Poboljsanje toka i kvalitete podataka o gradevnom otpadu i otpadu od istraživanja i eksploatacije mineralnih tvari u Republici Hrvatskoj, Aktivnosti 1.4, 3.2 i 3.3. Zagreb: HAOP i Građevinski fakultet Sveučilišta u Zagrebu.

Tonelli, M. i Cristoni, N. (2019). Strategic Management and the Circular Economy. New York i London: Routledge Taylor \& Francis Group.

Williams, I. D. (2015). Forty years of the waste hierarchy. Waste Management, 40: 1-2. Zakon o održivom gospodarenju otpadom. Narodne novine, 94/13. 


\title{
CONSTRUCTION WASTE AS AN IMPORTANT ELEMENT OF CORPORATE SOCIAL RESPONSIBILITY OF SMALLER CONSTRUCTION COMPANIES
}

\author{
Lana Lovrenčić Butković, Anđela Radić Stanišić and Mislav Ante Omazić
}

\begin{abstract}
Corporate social responsibility should not be a reactive measure that occurs only when sufficient pressure is placed on corporations. Rather, it should be an integral part of the responsibilities and practices of managers and decision-makers who must balance between various parties involved, environmental protection (on which the company may or may not have a direct influence), and the company's economic goals. Today, corporations are expected to conduct their business in line with long-term development strategies, which promote a systematic approach to sustainable development of all elements of society affected by the company. The aim of this paper is to analyze the management of construction waste in the context of social responsibility. Construction companies increasingly recognize the importance of waste management as one of the foundations of their sustainability and competitiveness. Therefore, corporate social responsibility is increasingly included in their strategies and practices, resulting in better business results and competitive advantage. In measuring corporate social responsibility of business entities, three key performance aspects, environmental, social and governance, their interaction and balance must be included in the analysis. As construction companies have a significant environmental impact, this paper asks whether a successful management of construction waste can be optimized, mainly from the environmental but also from the economic and social perspectives. The paper also looks at the classification of construction waste and its management. In order to accomplish this goal, we conducted research on four companies who collect and recycle construction waste using the interview method. The results reveal that these companies have collected most of the waste from medium and small construction companies and that they have exported the total of $53 \%$ of collected waste in 2018.
\end{abstract}

Key words: corporate social responsibility, construction industry, waste management, environmental protection, construction waste management

\section{BAUABFALL - EIN WICHTIGES ELEMENT DES SOZIAL VERANTWORTUNGSVOLLEN WIRTSCHAFTENS VON KLEINEREN BAUUNTERNEHMEN}

\author{
Lana Lovrenčić Butković, Anđela Radić Stanišić und Mislav Ante Omazić
}

\begin{abstract}
Zusammenfassung
Sozial verantwortungsvolles Wirtschaften von Unternehmen ist kein reaktives Konzept, zu dem es ausschließlich unter Druck von Akteuren kommt, sondern es geht um konkrete Aktivitäten und Verantwortung der Manager, deren Entscheidungen für die Balance zwischen Interessen von Akteuren und dem Umweltschutz sorgen müssen, d.h. ökonomischen Zielen und dem (in)direkten Einfluß auf die Umwelt. Heutzutage erwartet man von Unternehmen langfristige Entwicklungsstrategien mit einem einbezogenen systematischen Ansatz zur nachhaltigen Entwicklung von allen Elementen der Gesellschaft, die das Unternehmen beeinflußt. Das Ziel dieser Arbeit ist, auf die Wichtigkeit von Abfallwirtschaft hinzuweisen, vor allem auf das Recycling von Bauabfall, was ein Teil des Konzeptes des sozial verantwortungsvollen Wirtschaftens der Bauunternehmen darstellt, denn die Unternehmen sehen darin immer mehr die Basis ihrer Nachhaltigkeit und Konkurrenzfähigkeit. In dem Sinne werden sozial verantwortungsvolle Geschäftsaktivitäten immer stärker in Strategien aber auch in operative Geschäfte integriert, denn dies ist die einzige Vorgehensweise, bei der bessere Geschäftsergebnisse und Konkurrenzvorteile erreicht werden können. Wenn
\end{abstract}


sozial verantwortungsvolle Geschäftsaktivitäten von Geschäftssubjekten gemessen werden, beachtet man die drei wichtigsten Aspekte der Ausführung (den sozialen, den ökonomischen und den ökologischen), wichtig ist aber auch deren Wechselwirkung und Gleichgewicht. Da die Bauaktivitäten die Umwelt bedeutend beeinflußen, analysieren und erörtern wir in diesem Artikel die Möglichkeit einer erfolgreichen Abfallwirtschaft, vor allem aus der ökologischen, aber auch aus der ökonomischen und sozialen Perspektive. Im Artikel ist auch die Aufteilung von Bauabfall und Abfallversorgung dargestellt. Um das Ziel der Arbeit $z u$ verwirklichen, haben wir in vier Unternehmen, die sich mit Sammeln und Recyceln von Bauabfall beschäftigen, eine Forschung mit Interviews durchgeführt. Es hat sich ergeben, dass sie den größten Teil des Bauabfalls bei großen und mittleren Bauunternehmen gesammelt und im Jahr 2018 rund 53\% des gesammelten Abfalls exportiert haben.

Schlüsselwörter: sozial verantwortungsvolle Geschäftsaktivitäten, Bauindustrie, Abfallwirtschaft, Umweltschutz, Bauschuttversorgung 